PROCEEDINGS OF THE

TWENTY-THIRD INTERNATIONAL

MACHINE TOOL DESIGN AND RESEARCH

CONFERENCE 


\title{
PROCEEDINGS OF THE TWENTY-THIRD INTERNATIONAL MACHINE TOOL DESIGN AND RESEARCH CONFERENCE
}

held in Manchester

14th-15th September 1982

\author{
Edited by \\ B. J. DAVIES \\ Professor of Manufacturing Technology \\ Department of Mechanical Engineering \\ University of Manchester Institute of Science and Technology \\ Manchester
}

DEPARTMENT OF MECHANICAL ENGINEERING

UNIVERSITY OF MANCHESTER INSTITUTE OF SCIENCE AND TECHNOLOGY MANCHESTER

in association with

THE MACMILLAN PRESS LIMITED

$\mathbf{M}$ 
Department of Mechanical Engineering

University of Manchester Institute of Science and Technology 1983

Softcover reprint of the hardcover 1st edition 1983 978-0-333-34353-1

All rights reserved. No part of this publication may be reproduced or transmitted, in any form or by any means, without permission

First published 1983 by the Department of Mechanical Engineering

University of Manchester Institute of Science and Technology

P.O. Box 88, Manchester M60 1QD

\author{
in association with \\ The Macmillan Press Ltd \\ London and Basingstoke \\ Companies and representatives throughout the world
}




\section{TWENTY-THIRD INTERNATIONAL MACHINE TOOL DESIGN AND RESEARCH CONFERENCE \\ 14th-15th September 1982}

\section{CONFERENCE ORGANIZING COMMITTEE}

Chairman: Professor B. J. Davies

\section{POLICY COMMITTEE}

Professor S. A Tobias (Birmingham)

Professor W. Johnson (Cambridge)

Professor J. M. Alexander (Swansea)

\section{ORGANIZING AND REVIEWING COMMITTEE}

Professor B. J. Davies

Dr. C. F. Noble (Deputy Chairman)

Dr. J. Atkinson

Dr. G. Barrow

Dr. M. Burdekin

Dr. A. Cowley

Dr. M. Edkins

Dr. W. Graham

Dr. R. G. Hannam

Dr. J. Hawkyard

Dr. S. Hinduja

Dr. E. W. Smith

ORGANIZING SECRETARY

Mr. R. Kirk 


\section{CONTENTS}

\section{MACHINE ELEMENTS AND STRUCTURES}

Evaluation of the deflections of radial rolling bearings by nomograms

M.M. A. TAHA

The behaviour of a total cross flow hydrostatic journal bearing

M.E. Mohsin and A. Sharratt

A comparison of boundary integral and finite element methods for machine tool structural analysis

O. B. ALANKUS, R. D. HIBBERD and C. B. BESANT

Development of a machine tool structure using composite synthetic granite

S. E. OVEIAWE, T. TAY and A. A. SHUMSHERUDDIN

\section{MACHINE ANALYSIS AND TESTING}

The effect of assembly operations on the dynamic acceptance tests for machine tools

M. A. EL BARADIE

The energetic behaviour of crank presses

I. CZINEGE

Noise analysis of a $\mathrm{C}$-frame mechanical press

T. SANO, K. HATSUKANO, K. AOI and C. SODA

\section{MACHINE CONTROL SYSTEMS}

Design of a micro-computer based quality monitoring system for the manufacture

of knitting machine cylinders

H.S. GILL, N. D. BURNS and K. OLDHAM

Interpolation in hardware for numerical control: Evaluation of a new large-scale integrated circuit

T. W. SHAW and I. POON

Advanced CNC system using multibus compatible hardware and portable sof tware

G. M. AJIT and C. S. SRIDHAR

\section{QUALITY CONTROL}

Permanent temperature-control is securing technological processes in machine tools

H. WIELE, R. MANGELSDORF and H. HEINKE

An assessment of the potential of an industrial robot for use as a flexible drilling machine

J.A. G. KNIGHT and P. CHAPMAN

Development of in-process sensor for surface roughness measurement

I. INASAKI

Development of a new measuring method for spindle rotation accuracy by three points method

K. MITSUI

\section{TOOLING AND DATA FOR NC}

Optimizing tooling for CNC turning

M. A. KNIGHT and D. SPURGEON

A combined approach to obtaining and using tool life data

J. TAYLOR

Automation of postprocessors to increase productivity

K. G. ADAMS and D. FRENCH 


\section{CAD FOR NC}

A method of defining programming parameters for the manufacture of shoe moulds

D. FRENCH and K. G. ADAMS

Developments in the duct system of computer aided engineering

D. P.STURGE and M.S. NICHOLLS

Euklid and Ozelot, the linkage of a CAD and CNC-system

M. ENGELI and G.STAUFERT

\section{CUTTING PROCESSES}

Machining high strength materials: Cobalt-based alloys

M. WILSON and M. EL BARADIE

Tool life and performance data for various polycrystaline diamond tools including twist drills

D. K. ASPINWALL and G. MYATT

A study of rotary shaving by die-type cutting tool

S. KATO, K. YAMAGUCHI and T. NAKAMURA

\section{WHEEL DRESSING ASPECTS OF GRINDING}

Applications of continuous dressing in grinding operations

T.R.A. PEARCE and T. D. HOWES

Comparison of methods for truing and dressing diamond and boron nitride wheels

H. K. TONSHOFF and W. GARTNER

The significance of crushing roll infeed rate in the grinding wheel crushing operation

N. N. Z. GINDY and T. J. VICKERSTAFF

\section{GRINDING MACHINE PERFORMANCE}

Machine tools designed for borazon CBN

P.E. GRIEB

Design criteria for $\mathrm{CNC}$ tool and cutter grinding

L. ACARNLEY, D. A. POWELL, G. J. TRMAL and M. J. TYLER

The task of grinding of casting surfaces with industrial robots

G. STUTE and K. H. WURST

\section{ELECTROCHEMICAL MACHINING}

An experimental investigation on the sound speed and "choking" phenomenon of gas-liquid two-phase flow in the electrochemical machining (ECM) gap

C. Y. YU, Y. Q. WANG, J. W. XU and D. ZHU

Computer aided analysis of ECBD process

VIJAY K. JAIN, VINOD K. JAIN and P. C. PANDEY

Electro chemical creep feed grinding with, Ni-coated WA wheel

Y.KITA, M. IDO, M. KUNO and A. MIGUCHI

\section{ELECTRO-DISCHARGE MACHINING}

The influence of EDM pulse shape on machined surfaces

F. SCALARI and M. VIGNALE

Role of dielectric flushing on EDM performance

$$
\text { A. ERDEN }
$$

An approach to identification and multicriterion optimization of EDM process

A. OSYCZKA, J. ZIMNY, J. ZAJAC and M. BIELUT 


\section{UNUSUAL MANUFACTURING PROCESSES}

Study of a thermal energy method of removal of surface irregularities

W.E. GEORGE and J. A. McGEOUGH

A new die manufacturing process suitable for FMS of press forming in large variety production

K. KAWAGUCHI, S. HIRAMOTO, O. HAMADA and W. SHIMADA

Electrical discharge compaction technique for welding rod manufacture

A. F. DARVIZEH, M. CAN, T. J. DAVIES and S. T.S. AL-HASSANI

Production of fine short-length metal fibres using self-excited vibration of an elastic tool

\section{CROPPING METHODS FOR TUBE AND BAR}

A survey of methods for producing tubular billets by shearing

C. K. CHOONG, M.K. DAS and S. A. TOBIAS

The study of precision bar cropping under axial load (Part II)

C. JINDU, Z. XIANRU, Z. ZIGONG, Y. DEHONG, T. ZHAOJUE and T. GUOHUA

\section{EXTRUSION AND DRAWING}

Theoretical and experimental analysis of tube and hollow profile extrusion

T. ABILDGAARD

Study of asymmetric extrusion and drawing of tube - analysis of inclined wall-thickness distribution of tube M. KIUCHI and M. ISHIKAWA

Hydrostatic extrusion/drawing of tubes with a fixed mandrel

B. LENGYEL and M. J. M. B. MARQUES

Enhanced hydrodynamic lubrication in hydrostatic extrusion using a modified die

S. THIRUVARUDCHELVAN

\section{FURTHER FORMING STUDIES}

Cold form tapping of internal threads

P.H.H.TRENDLER and T. HODGSON

On the warm forming of machining steels

E. NEHL and K. POHLANDT

Deformation and temperature distribution in hot forging

H. SAIKI, S. SHIMIZU, E. TSURU and T. MATSUO

\section{JOB SHOP CONTROL AND PROCESS PLANNING}

Single queue management of a job shop as implemented by a data flow architecture

W. C. LEWIS, M. M. BARASH and J. J. SOLBERG

Tool oriented automatic process planning

W. C. LEWIS, E. BARTLETT, I. FINFTER and M. M. BARASH

Increasing economy by re-organization the field of cutting tools in computer aided design, planning and

manufacturing

H. K. TONSHOFF and J. BALBACH 


\section{FACTORY LAYOUT}

Computer-aided plant relayout

S.E.Z. ABDEL-BARR and M. M. KOURA

Simulation study of "unbalanced" flow line production systems

D. S. HIRA and P.C. PANDEY

Optimal plant location

M. A. ISMAIL and G. A. E. SEWELL

\section{FLEXIBLE MANUFACTURING SYSTEMS}

FMS software: Data structures of distributed FMS data bases

P.G. RANKY

Use of the cluster-analysis for developing a flexible manufacturing system for rotational parts H. K. TONSHOFF, C. FREIST, R. GRANOW and J. BUSSMANN

Flexible manufacturing system complex provided with laser (FMC)

M. KIMURA, C. SODA, S. OZAKI, Y. YOSHIDA, M. KANAI AND Y. ITOH

Modelling a multi-product manufacturing system to assist in the selection of CNC machine tools B. R. KILMARTIN, D. HUGHES and R. LEONARD

Dialogue oriented workshop order scheduling in flexible automated manufacturing G. SPUR, G. SELIGER and A. EGGERS

Description of machining function in FMS and ITS analysis

Y. ITO, Y. SAITO and T. KUDAMA

Fault analysis in a flexible manufacturing cell

P. K. WRIGHT, D. A. BOURNE and R. M. MILLIGAN

\section{AUTOMATION AND ROBOTICS}

Government attitudes toward programmable automation

J. A. ALIC

Economic considerations in industrial robotics

P. L. WATTS, A. LEWIS and B. K. NAGPAL

The design of a DNC system for use in the production of small, prismatic parts

D. H. J.HANCOCK 


\title{
FOREWORD
}

\author{
BY CONFERENCE CHAIRMAN
}

It gives me great pleasure to preface the proceedings of the latest conference in a long line of international forums. The presentation of papers and exchange of information and views by eminent researchers and industrialists has continued unabated for twenty-three years. Many of the young engineers who now attend as delegates or even submit papers were not born when the conference series started in 1960. During the early years the majority of papers came from the UK with countries in Europe a close second. Since those days, design, manufacturing and supply of machine tools and associated equipment has become increasingly international and competitive. Such internationalism is exemplified by the fact that 45 of the 63 contributing papers for 1982 come from 21 different countries outside the UK. This year Japan, and last year the Peoples Republic of China, head the list of overseas contributors whom we are pleased to welcome to Manchester.

The trend from specific design studies to the wider theme of manufacturing engineering has been natural and welcomed by both delegates and those who subsequently read and study the proceedings. It acknowledges that manufacturing industry is the most important creator of wealth within developed countries and that a sound industrial base is a vital element in enhancing the standard of living in countries still developing.

Perhaps because of my own special area of interest, I particularly note the increasing growth of research and development in Integrated Manufacturing Systems. Topics in this area include CAD, FMS and Robotics, all of which are demonstrably efficient and economical ways of manufacturing batches of capital goods. The manufacture of machine tools themselves is utilising these methods and stands as an example and warning to all who are not prepared or able to innovate.

Despite its pioneering role with System 24 the UK has been slow to install Flexible Manufacturing Systems, but it is a pleasure to be able to report that we now have 16 systems at various stages of development, most with the assistance of DoI. The $160 \mathrm{M}$ FMS programme announced by the Minister for Information and Technology in June is particularly welcome. Through this programme UK companies can recover $50 \%$ of the cost of consultancy from DoI up to $£ 50,000$, and up to a third of the total capital cost. Parallel developments in the SERC are assisting universities to carry out essential related research.

This conference contributes to a wider understanding of the problems and opportunities in this field and it does so without losing sight of the fundamental aspects of design and process analysis upon which new technologies depend.

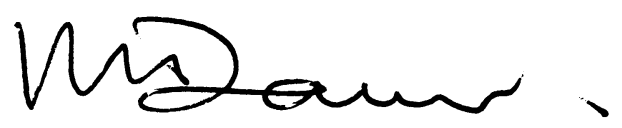

